\title{
Effect of Addition of Graphite on Tribological Behaviour of Sic and Fly Ash Reinforced Copper Based Self-Lubricating Composites
}

\author{
P. Balamurugan, M. Uthayakumar
}

\begin{abstract}
In the present study 4 different combinations of composites are prepared with varying proportions of graphite content by keeping the same proportion of copper, SiC and Fly ash through powder metallurgy process. hardness, Microstructure and tribological properties are studied with varying sliding velocities $(1,2 \& 3 \mathrm{~m} / \mathrm{s})$ and loading conditions (10, 30 and $50 \mathrm{~N})$. The addition of graphite reduces the hardness, but the wear behaviour is enhanced with its addition.
\end{abstract}

\section{Keywords : Copper, Flyash, SiC, Composite}

\section{INTRODUCTION}

Friction in the mating surfaces is the major problem in machine components, in order to reduce the friction lubrication is provided between the mating surfaces. The lubrication in the form of liquid or semisolid cannot be used in various conditions such as extreme temperature or pressure, vacuum and radiation etc., under the above circumstances material with self-lubricating property is preferred. Self-lubricating property can be achieved in the metal matrix composites by adding solid lubricants as reinforcements during processing of composites. Soft reinforcement materials such as graphite[1], molybdenum di-sulphide[2] and carbon nano tubes[3] having the self-lubricating characteristics are added in the metal matrix to reduce the friction coefficient. Generally, materials with high hardness such as $\mathrm{SiO}_{2}$ [4], $\mathrm{SiC}[5]$, Fly ash[6], B4C[7], WC[8] and $\mathrm{TiC}[9]$ are added to the matrix to reduce the loss of material from the surface, but the addition of above reinforcements to the metal matrix based on aluminium or copper increases the coefficient of friction which may lead to greater noise at higher loading conditions. The addition of solid lubricants along with the oxide or carbide reinforcements reduces the coefficient of friction[10]. In the present study, the tribological properties of the composites prepared with constant reinforcement proportion of silicon carbide, fly ash with different proportions of graphite on copper matrix is studied.

Revised Manuscript Received on December 15, 2019.

* Correspondence Author

P. Balamurugan*, School of Automotive and Mechanical Engineering, Kalasalingam Academy of Research and Education, Krishnankoil, India. Email: pbala.klumech@gmail.com

M. Uthayakumar, School of Automotive and Mechanical Engineering, Kalasalingam Academy of Research and Education, Krishnankoil, India. Email:uthaykumar@gmail.com

\section{MATERIALS AND METHODS}

Copper with $99.7 \%$ purity is mixed along with 5\%(vol.) of Sic and 5\%(vol.) of Fly ash is used as the base proportion. In addition to it, graphite with varying volume proportions of $1 \%, 2 \%$ and $3 \%$ is used to form different composites. The average particle size of the copper, $\mathrm{SiC}$, fly ash and graphite are $30 \mu \mathrm{m}, 50 \mu \mathrm{m}, 10 \mu \mathrm{m}$ and $100 \mu \mathrm{m}$ respectively. The composites were prepared by powder metallurgy technique, in which the compaction pressure is considered as $450 \mathrm{MPa}$ for compaction of the materials after blending the powders of $\mathrm{Cu}, \mathrm{SiC}$, Fly ash and Graphite manually in a mortar. The green specimen was sintered at $900^{\circ} \mathrm{C}$ for 60 minutes[11]. Microstructure of the prepared composites is analysed using optical microscopy and the hardness is measured using vicker's hardness tester for a load of $0.5 \mathrm{kgf}$. Tribological tests were conducted for loads of $10 \mathrm{~N}, 30 \mathrm{~N}$ and $50 \mathrm{~N}$ for the sliding velocity range of $1-3 \mathrm{~m} / \mathrm{s}$ in steps of increase of $1 \mathrm{~m} / \mathrm{s}$. Wear tests were conducted on pin on disc setup to find the friction coefficient and wear rate under the stated loading and sliding velocity conditions

\section{RESULTS AND DISCUSSION}

Microstructure of the composites prepared is shown in the Fig. 1. Microstructural results as shown in fig. 1indicates that with the rise in graphite content, more agglomeration of the graphite is witnessed due to its soft nature. The hardness test results are shown in the Table - I. It is noted that there is a drastic downfall in the hardness value with addition of graphite content.

Table - I. Vickers hardness test results

\begin{tabular}{|l|c|}
\hline \multicolumn{1}{|c|}{ Sample } & $\begin{array}{c}\text { Hardness measured } \\
\text { in HV }\end{array}$ \\
\hline Composite with no graphite & 60 \\
\hline Composite with 1\% of graphite & 52 \\
\hline Composite with 2\% of graphite & 45 \\
\hline Composite with 3\% of graphite & 38 \\
\hline
\end{tabular}

Results of the tribological test is shown in Fig. 2. From the results it is noted that as the sliding velocity rises from $1 \mathrm{~m} / \mathrm{s}$ to $3 \mathrm{~m} / \mathrm{s}$ for all combinations of composites the wear rate decreases, this might be due to the formation of thin lubrication layer due to plastic deformation of the graphite, as the load increases the film formation breaks and the bare metal comes in contact with the counterpart which increases the wear volume removed from the material being tested. 


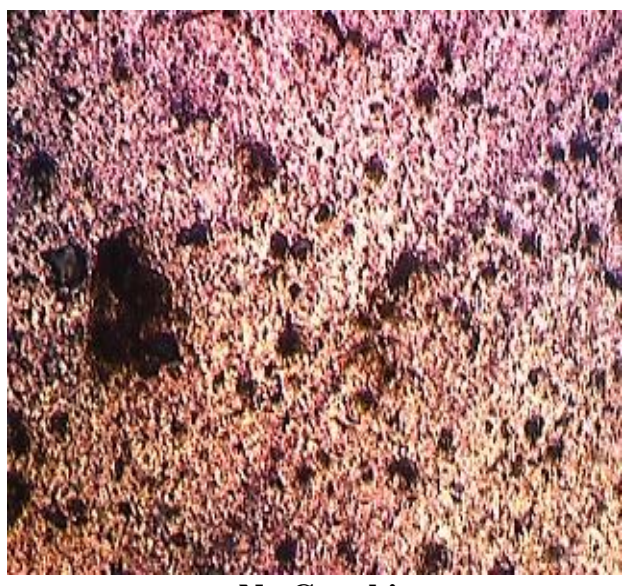

a. No Graphite

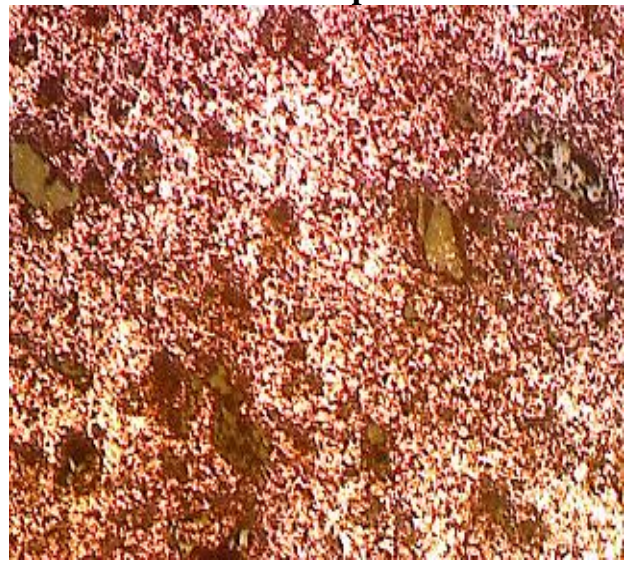

c. $2 \%$ Graphite

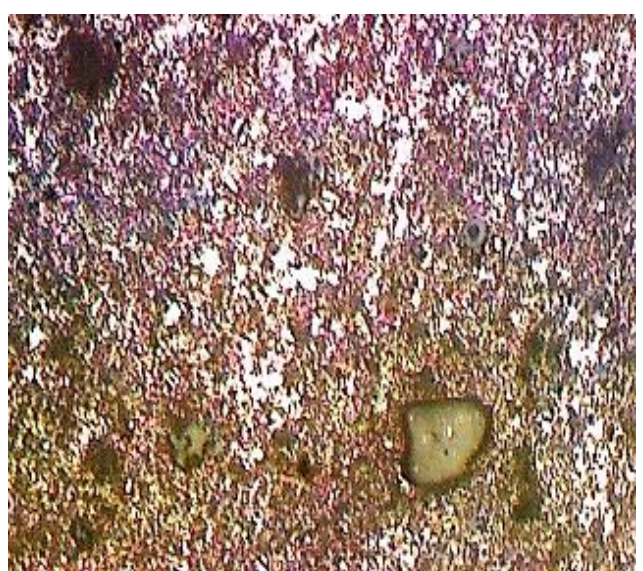

b. $1 \%$ Graphite

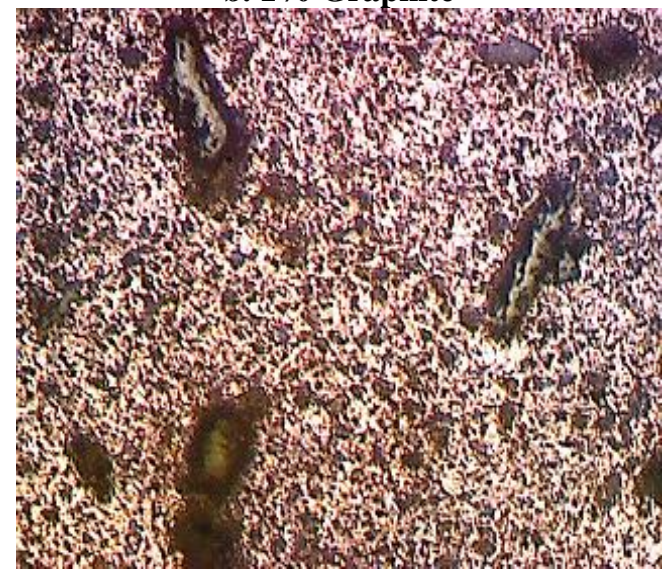

d. 3\% Graphite

Fig. 1. Optical micrographs of the composite with varying graphite content: (a) no graphite, (b) $1 \%$ Graphite, (c) $2 \%$ Graphite and (d) $3 \%$ Graphite
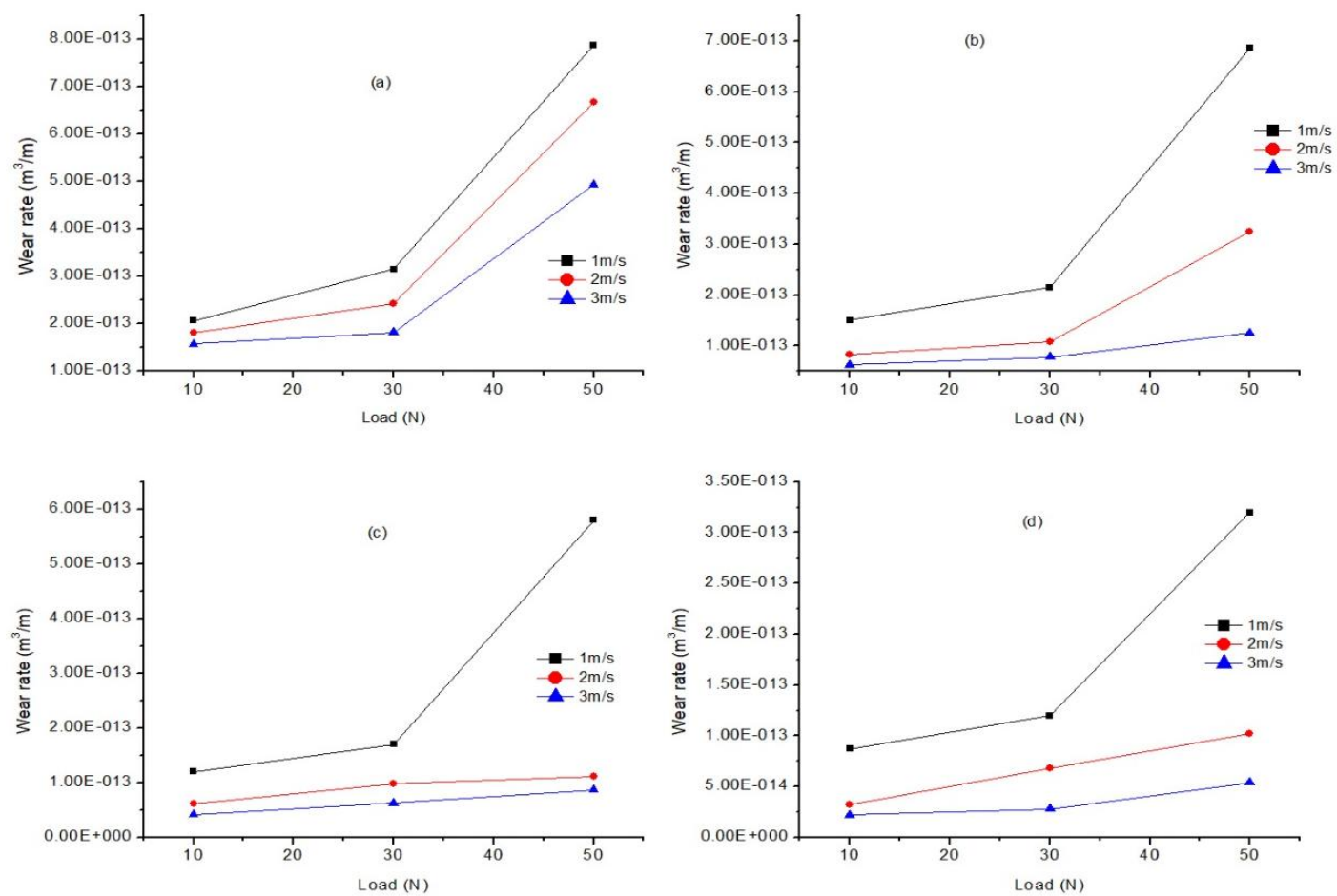

Fig. 2. Wear studies under varying sliding velocities for the composites with (a) no Graphite, (b)1\% Graphite, (c) $2 \%$ Graphite and (d) $3 \%$ Graphite

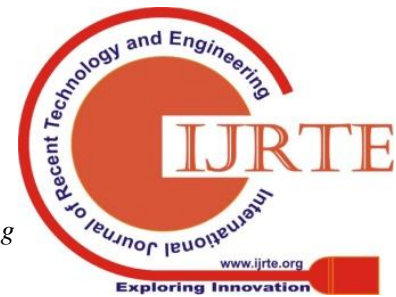




\section{CONCLUSION}

- Hardness of the composite reduces with the rise in graphite reinforcement to the composite due to its soft nature

- $\quad$ Addition of graphite content to $\mathrm{Cu}-\mathrm{SiC}-\mathrm{Fly}$ ash composite decreases the wear rate due to formation of lubrication layer over the sliding surface

- The wear rate of the composites irrespective of the combination increases with the increase in load

\section{REFERENCES}

1. S. Mahdavi and F. Akhlaghi, "Fabrication and characteristics of Al6061/SiC/Gr hybrid composites processed by in situ powder metallurgy method," J. Compos. Mater., May 2012.

2. Y. Zhang, Y. Epshteyn, and R. R. Chromik, "Dry sliding wear behaviour of cold-sprayed $\mathrm{Cu}-\mathrm{MoS} 2$ and $\mathrm{Cu}-\mathrm{MoS} 2-\mathrm{WC}$ composite coatings: The influence of WC," Tribol. Int., vol. 123, pp. 296-306, 2018.

3. K. Rajkumar and S. Aravindan, "Tribological studies on microwave sintered copper - carbon nanotube composites," Wear, vol. 270, no. 9-10, pp. 613-621, 2011.

4. K. A. Ragab, R. Abdel-Karim, S. Farag, S. M. El-Raghy, and H. a Ahmed, "Influence of $\mathrm{SiC}, \mathrm{SiO} 2$ and graphite on corrosive wear of bronze composites subjected to acid rain," Tribol. Int., vol. 43, no. 3, pp. 594-601, Mar. 2010.

5. A. K. Mishra, R. Sheokand, and R. K. Srivastava, "Tribological Behaviour of Al-6061 / SiC Metal Matrix Composite by Taguchi's Techniques," vol. 2, no. 10, pp. 1-8, 2012.

6. M. Uthayakumar, S. T. Kumaran, and S. Aravindan, "Dry Sliding Friction and Wear Studies of Fly Ash Reinforced AA-6351 Metal Matrix Composites," vol. 2013, 2013.

7. S. T. Kumaran, M. Uthayakumar, and S. Aravindan, "Dry sliding wear behavior of $\mathrm{SiC}$ and B 4 C-reinforced AA6351 metal matrix composite produced by stir casting process," vol. 0 , no. 0 , pp. $1-8$, 2015.

8. A. Lekatou et al., "Aluminium reinforced by $\mathrm{WC}$ and $\mathrm{TiC}$ nanoparticles ( ex-situ ) and aluminide particles ( in-situ ): Microstructure, wear and corrosion behaviour," Mater. Des., vol. 65, pp. 1121-1135, 2015.

9. K. Rajkumar and S. Aravindan, "Tribological performance of microwave sintered copper - TiC - graphite hybrid composites," Tribol. Int., vol. 44, no. 4, pp. 347-358, 2011.

10. G. Cui et al., "Synergistic effect of alumina and graphite on bronze matrix composites: Tribological behaviors in sea water," Wear, vol. 303, no. 1-2, pp. 216-224, Jun. 2013.

11. P. Balamurugan and M. Uthayakumar, "Influence of Process Parameters on $\mathrm{Cu}-\mathrm{Fly}$ Ash Composite by Powder Metallurgy Technique," Mater. Manuf. Process., vol. 30, no. 3, pp. 313-319, 2015.

\section{AUTHORS PROFILE}

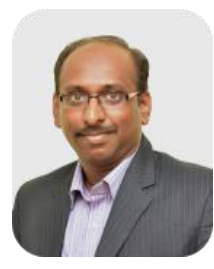

Dr. P. Balamurugan has obtained his Doctoral Degree from Kalasalingam University, India. He is doing research in the area of Characterization, Mechanical, Tribological, Corrosion and erosion studies of metal matrix composites. Currently he is working as Associate Professor in Department of Mechanical Engineering, Kalasalingam Academy of Research and Education, India.

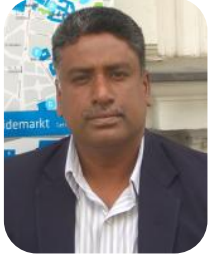

Dr. M. Uthayakumar has obtained Master of Engineering in Production Engineering from Thiagarajar College of Engineering (Autonomous), Madurai, India and Doctorate from Department of Production Engineering, National Institute of Technology, Tiruchirappalli. He has published 145 papers in the international journals and conference. Currently he is a Professor at Department of Mechanical Engineering, Kalasalingam Academy of Research and Education, Krishnankoil, Virudhunagar Dist. 